\title{
The Relationship Between Microbiology as a Science and the Microbiology Subject
}

\author{
Lilianne Dominguez Céspedes ${ }^{1,}$, , Yohorlin Marta Céspedes Fonseca ${ }^{2}$ \\ ${ }^{1}$ Microbiology Department, "Lucia Iñiguez Landin” Surgical Clinical Hospital, Holguin, Cuba \\ ${ }^{2}$ Dermatology Department, "Lucia Iñiguez Landin” Surgical Clinical Hospital, Holguin, Cuba \\ Email address: \\ ldominguezc@infomed.sld.cu (L. D. Céspedes), yohorlinhlg@infomed.sld.cu (Y. M. C. Fonseca) \\ ${ }^{*}$ Corresponding author
}

\section{To cite this article:}

Lilianne Dominguez Céspedes, Yohorlin Marta Céspedes Fonseca. The Relationship Between Microbiology as a Science and the Microbiology Subject. Chemical and Biomolecular Engineering. Vol. 6, No. 3, 2021, pp. 43-48. doi: 10.11648/j.cbe.20210603.11

Received: May 18, 2021; Accepted: June 9, 2021; Published: July 22, 2021

\begin{abstract}
From ancient times to the Renaissance, science constitutes a knowledge that is based on the contemplation of nature. The use of the preceding results, their permanent modification, the crossing of information, models, is what constitutes science, in a cumulative tradition of knowledge and practices. The objective of this work is to contribute to the knowledge of the history of microbiology and its role in the education and preparation of future doctors. Our knowledge of microbes has had a negative side, since they are the causative agents of infectious diseases, contamination and deterioration of food, materials, etc. After the golden age of Bacteriology, inaugurated by great figures such as Pasteur and Koch, Microbiology remained for some time a descriptive and applied discipline, closely interwoven with Medicine, and with a development parallel to that of Chemistry, which it would contribute several fundamental methodological advances. Our knowledge of microbes has had a negative side, fear, since they are the causative agents of infectious diseases, and of contamination and deterioration of food, materials, etc. However, we are beginning to realize that we are completely dependent on microbial life. Life not only began with prokaryotic microorganisms, but the continuity of the very existence of life on Earth rests with them. The Microbiology subject is essential to understand the functioning of ecosystems and the interactions between the atmospheric, aquatic and terrestrial environment. Our objective is that, after taking the course, the student has acquired a global vision about the microbial world, the impact of microorganisms in the environment and their possible use in technological processes associated with the environment. We emphasize the importance of Microbiology in medicine and other related careers.
\end{abstract}

Keywords: Science, Microorganisms, Microbiology, Teaching

\section{Introduction}

From ancient times to the Renaissance, science constitutes a knowledge that is based on the contemplation of nature. It is through observation and reasoning that it is possible to access the essence of nature. When dealing with nature (in general with reality), contemporary science does so through the set of mediations that throughout its development science and technology itself have come building: models, theories, instruments, technologies and it is through them that the investigation. The research refers to the knowledge production activity that unfolds from the previous results expressed in models, laws, theories and also, instruments, equipment, experiences, skills, all of which are constructs created by man in order to explain and handle. Scientists appeal to these resources created not only in their own fields of research but using those that come from others, sometimes distant. This use of the preceding results, their permanent modification, the crossing of information, models, is what constitutes science in a cumulative tradition of knowledge and practices. [1] The review to academic articles was related to the history of microbiology, its teaching at an international level and the study plans of the subject microbiology in Cuba.

The objective of this work is to contribute to the knowledge of the history of microbiology and its role in the education and preparation of future doctors. 


\section{Development}

\subsection{Historical Development}

Scientific development is a continuous interaction between facts and ideas. Advances in the knowledge of the natural world are normally preceded by technological innovations that allow new measurements and observations of the world around us, and also to devise experimental situations that would not have been possible before. The techniques, despite their extraordinary utility, are only tools that need intellectual preparation to reach knowledge and interpret reality: "Chance only appears in prepared minds" (in the words of Louis Pasteur). [2-4]

The verification and logical confirmation of the explanatory structures of scientific theories, after examining and evaluating scientific practice (through the critical task of epistemology) was linked, from the constant evolution of applied sciences, to the emergence of new theories and alternatives with greater explanatory power, to solve the problems that science deals with. Seneca, wrote in the 1st century AD. "The letters, however small and indistinct, are seen more enlarged and more clearly through a glass globe filled with water."

For his part, Roger Bacon, in 1267, commented: "great things can be accomplished through refracted vision. If the letters of a book, or some small object, are seen with a small sphere of the glass or glass, whose plane is adjacent to them, will appear better and larger. " The conceptual evolution of the historically called "Art of curing" that begins with a hygienic conception, proposed by Hippocrates and taken up by Galen, had its transition to concepts such as the anatomoclinical and the etiopathological, the latter, the cradle of the development of Bacteriology, the which, according to Iáñez, is supported by advances in techniques and instruments, including the microscope, whose invention in the seventeenth century is the starting point, within the framework of profound secular controversies, of a science that still amazes us for its ability to highlight those beings and compounds with size below the resolving power of the human eye and discover its beneficial and morbid potential. The vitalists assumed that the structure that characterizes life must be the residence of a principle hidden vital. One of the oldest ideas is the fibrillar theory, which probably arose from the observation of macroscopic fibrous structures, such as muscle fibers, veins, and nerves. Looking at globular structures under the microscope, the idea of the globule arose and the establishment of a globular current complementary to the fibrillar theory.

The globulists, who based their ideas on the observations of such important microscopists as Marcelo Malpighi (16281694) or Anton Van Leeuwenhoek (1632-1723), did not pretend to replace fiber as a fundamental constituent of life. They simply found in these globular structures, called "granuli globuli" by Malpighi and "protruding globules" by Leeuwenhoek, the origin of the fibers that they still considered carriers of life force. Normally, the discovery of the cells was assigned, a name given to them because of their resemblance with the cells of a honeycomb, to Robert Hooke (1635-1703), who communicated his observations to the Royal Society of London in the year 1667. But around that same time, the beginning of the 19th century, the fibrillar theory began to give way ground to globular theory, which constitutes the first approach to modern cell theory.

Hooke's discovery and the earlier observations of the Dutch microscopist Van Leeuwenhoek, who opened the window to the world of the microscopic, were received as a "curiosity" by the rest of the naturalists, as an object of admiration, but unimportant for the scientific reflection. Towards the end of the 18th century and the beginning of the 19th century, a renewed interest in solving the enigmas of nature. Mainly in Germany, where a philosophical current called "Naturphilosophie" or philosophy of nature, which vigorously promoted research in the different branches of natural sciences, including microscopic studies.

With the recognition of the microbial origin of the fermentations, the definitive abandonment of the idea spontaneous generation and the triumph of the germinal theory of disease, establish the principles of a science, Bacteriology, which according to Patrick Collard's scheme, in "The Development of Microbiology", written in 1985, has four stages or periods: first period, eminently speculative, that extends from antiquity until reaching the first microscopists; second period, of slow accumulation of observations (from approximately 1675 to the middle of the 19th century), which begins with the discovery of microorganisms by Leeuwenhoek (1675); third period, of cultivation of microorganisms, which reaches the end of the 19th century, where the figures of Pasteur and Koch lead the achievement of crystallizing Microbiology as a wellestablished experimental science; fourth period (from the beginning of the 20th century to the present day), in which microorganisms are studied in all their physiological, biochemical, genetic, ecological complexity, etc., and which supposes an extraordinary growth of Microbiology, the emergence of microbiological disciplines specialized as Virology, Immunology and Mycology, and the close interweaving of microbiological sciences in the general framework of Biological Sciences.

Leeuwenhoek's careful observations revealed a world of microscopic animalcules whose existence was not even suspected. But neither he nor his contemporaries correlated their descriptions of the microscopic world with the existence of elemental units of life. Similar was the case of another of the great microscopists like Malpighi, discoverer of various structures in animals and plants, some of which still bear his name. For most of the 18th century, there was a great stagnation in the description of microscopic structures. Leeuwenhoek observed muscle fibers and blood vessels (1668), and even went so far as to accurately describe and draw structures such as red blood cells (1674) and human sperm (1679). During the next two centuries, microorganisms were forgotten, appearing again on the scene to be observed in compound microscopes, with much higher resolving power than that designed by Leewenhoeck, and which were 
fundamental in the transition from Observational Medicine to Laboratory Medicine., originated in the bacteriological discoveries of Louis Pasteur and Robert Koch, and in the pathophysiological knowledge of Claude Bernard, from the positivist perspective of the experimental method of Augusto Comte, the embryogenic basis of an institutionalized knowledge in the last two decades of the 19th century in Europe and North America. The German physician Robert Koch and the French chemist Louis Pasteur opened their eyes to the microscopic world. Koch had the ingenuity and discipline to transform the modernist interest in bacteria in the society of his time, and relate them to diseases, thus originating Bacteriology and endowing it with the postulates to follow to establish the association between disease and agent, to starting from observations and experiments with which he could anticipate all the objections of the unbelievers.

Imagination, intelligence and struggle with the dominant paradigms were the elements that characterized the pioneers of Bacteriology in Europe in the 19th century. Metchnikoff, Behring, Pasteur and Koch and many others who worked silently in the research teams of these scientists, are due to have revealed the existence of infectious agents, who, under the cover of their invisibility, managed to fight and win great battles against a humanity hitherto ignorant of its scope. The findings in Bacteriology made by Pasteur and Koch, and their usefulness in understanding the origin of the disease, gave way to a scientific revolution that profoundly altered the anatomoclinical and pathophysiological mentality, and gave way to the etiopathological mentality that recognizes microorganisms the first external cause of disease. [5]

After the golden age of Bacteriology, inaugurated by great figures such as Pasteur and Koch, Microbiology remained for some time a descriptive and applied discipline, closely interwoven with Medicine, and with a development parallel to that of Chemistry, which it would contribute several fundamental methodological advances. However, a current, in principle a minority, dedicated to basic studies focused on certain soil bacteria possessing special metabolic capacities, including the discovery of those that affect plant nutrition, managed to show the ecological ubiquity and the extreme physiological diversity of microorganisms. In this way, a bridge was established between Microbiology and other biological sciences, which reached its decisive moment when the chemical unity of the entire living world was verified, and it was demonstrated, with material and microbiological techniques, that the heredity molecule it was deoxyribunucleic acid (DNA). With this, an intimate and fertile exchange between Microbiology, Genetics and Biochemistry is witnessed, which is reflected in the birth of Molecular Biology, the basis of the spectacular rise of Biology since the middle of the last century. On the other hand, the initial "program" of Microbiology (search for infective agents, unraveling and taking advantage of the host's defense mechanisms) led to the creation of subsidiary sciences (Virology, Immunology), which finally came of age and an accentuated autonomy. [6]
Our knowledge of microbes has had a negative side, fear, since they are the causative agents of infectious diseases, and of contamination and deterioration of food, materials, etc. However, we are beginning to realize that we are completely dependent on microbial life. Life not only began with prokaryotic microorganisms, but the continuity of the very existence of life on Earth rests with them. The simple observation of a bacterium under a microscope is not very revealing. Most look like simple rods or small spheres without any distinctive features. Despite this apparent morphological simplicity, bacteria have enormous metabolic diversity that allows them to occupy very diverse ecological niches and to be the basis of all food webs in the biosphere. [2-4]

\subsection{Current Microbiological Trends}

Frequently, several important scientific contributions to Microbiology made in more years close to our time they have occupied the attention of the general public and have been collected in the pages of newspapers, also occupying the center in other media. Even today we still perceive the echoes of some recent events related to Microbiology. One of the most striking was the consequence of the discovery by Prusiner (Nobel 1997) of prions. These agents are infectious particles of a protein nature that lack nucleic acid and are related to lethal neurodegenerative diseases that receive the generic name of spongiform encephalopathies. among which is the so-called "mad cow disease". The multiplicative strategy of prions is revolutionary and unprecedented because they propagate without the help of nucleic acid. When in contact with homologous normal molecules, they force the transformation of their original configuration to a prion structure that, in turn, amplifies the effect. Considering that the Multiplication capacity constitutes the essence of life, and that, on the one hand, all previously discovered infectious agents consisted of protein and nucleic acid (except virions that only possess nucleic acid) and that, on the other hand, this capacity implied always the replication of the nucleic acid, it seemed that the difference between being nucleoprotein or simply protein should be practically the same as between something alive or dead. However, prion proteins appear alive because they multiply by a unique conversion mechanism from other molecules, making it more difficult to define life in molecular terms. In the early $21 \mathrm{st}$ century, studies by Nurse and others (Nobel 2001) revealed regulatory issues that are key to understanding the cell division cycle. In this context, it was surprising to see that the conclusions of their studies, carried out mainly using the yeast Schizosaccharomyces pombe, were valid for cells of other higher species, including man. Another more recent, and somewhat more unknown, milestone is the discovery by Marshall and Warren (Nobel 2005) that the Helicobacter pylori bacteria are responsible for both stomach ulcers and gastritis, and antibiotics are effective in treating these conditions. [7]

Almost nowadays, the appearance of cases of infection by various viruses, such as SARS (severe acute respiratory 
syndrome), bird flu or Ebola, or Bacillus spore bioterrorism episodes remind us that pathogens can continue to be an occasional threat to our species. This situation recalls the words of Pasteur when he said: "Gentlemen, it is the microbes that will have the last word." It seems, in fact, that this may be the case, since microorganisms evolutionarily preceded us and, with all certainty, will remain on Earth when man disappears as a species. In recent times, creating artificial life represents a challenge with off-limits implications of science and raises social, economic and even theological questions. In this regard, all the media recently highlighted a series of experiments that some considered the creation of life, although the real issue has its limitations. What the team led by the American Venter achieved is the introduction of the genome of a bacterium called Mycoplasma mycoides into cells of another bacterial species (Mycoplasma capricolum) from which the genome had previously been deleted. The The final result is that the recipient bacteria, which became a different species (Mycoplasma laboratorium), acquired, as expected, the physiological characteristics of the donor bacteria. Perhaps the most remarkable thing about the famous result is that the genome used in this transformation was chemically synthesized, but it must not be forgotten that the receptor system was a pre-existing normal cell devoid of its genome. Therefore, one cannot speak in the strict sense of life created in a laboratory because, except for the transferred genome, the rest of the macromolecular machinery of the resulting cell was not newly created. In other words, it is about modification rather than creation. However, nuclear transfer or cloning in the case of higher cells may constitute one of the fundamental pillars for the development of a synthetic biology whose results may surprise us in the future. The studies by Venter and his collaborators have an unquestionable dimension, but unlike the terms frequently used in the media, no serious scientist can properly speak that his results constitute a creation of life. The true origin of life began at least 3.5 billion years ago in a way that we still do not fully understand, although the path to its better understanding has been started. Recent evidence for the existence of macrobacteria and nanobacteria has greatly expanded the scale of the material object of Microbiology and revealed fascinating aspects of microorganisms. The estimates made on the existing microbial species are surprising. Metagenomic studies indicate that the set with the greatest diversity in the biosphere is the microbial one, with a repertoire of genes and capacities that exhibits greater flexibility than that present in plants or animals and that in physiological terms we do not know more than $1 \%$ of the existing variety. It is considered that there are at least $5 \times 1031$ microbial cells on the planet, with a weight equivalent to 50,000 billion $\mathrm{Tm}$. Although it is difficult to have a dimensional idea of what microorganisms represent, keep in mind that being invisible to the naked eye does not mean being absent but, on the contrary, being able to be very distributed.

As an example, a single gram of soil can contain about 100 million bacteria, and good agricultural soil the size of a football field is typically home to a microbial population whose total weight is close to that of a cow grazing on that field. Other estimates suggest that microorganisms constitute $90 \%$ of the total biomass of the biosphere if cellulose is excluded from the calculation or $60 \%$ if the presence of this natural polymer is included. To quantitatively materialize its impressive presence, it is enough to add that the study of the human microbiome reveals that strange as it may seem in terms of the total number of cells, our own body contains more microbial cells than human cells. [7]

\subsection{Reflection of Issues in Teaching}

The 2030 agenda for sustainable development has 17 objectives, of which the number 4 is related to quality education. It is important to note that this objective has goals to meet during its application, among them is: to train a professional with a broad profile who meets the demands of the society in which he is trained. [8]

Science teaching takes on an important role in the training of students in any educational system, since scientific literacy for all people becomes a necessity for equal opportunities in the 21 st century. For its part, UNESCO in 1998 declared the importance of teaching them as a means to promote and develop critical thinking that allows solving different problems in different areas. On the other hand, the disciplines they include are in charge of developing the necessary skills for responsible interaction with the environment that surrounds all the individuals who inhabit the planet. [9]

In this sense, one of the disciplines that contribute to the above is Microbiology and Medical Parasitology. The knowledge of microbiology belongs to that of the Natural Sciences; this type of scientific knowledge is knowledge propositional, which is methodical because it has a method to justify the results it achieves. Scientific theories originate from the results of the experiences; this way of presenting the results of science is what is known as its systematic nature. The explanatory character implies the fact that a law or a set of laws can explain the occurrence of a phenomenon through deductive procedures. Therefore, it can be affirmed that the explanatory character implies systematization. [10]

The medical schools have constantly changed the curricula throughout the world and a proportional change has occurred in the organization of medical education, which has been manifested in their philosophy, in the programs, in the technologies for the teaching and in the evolution of knowledge, which in the field of medical education is the consequence of the impact that scientific-technical development has on such education in the last decades of the 20th century and the first decades of the $21 \mathrm{st}$, the health organization public, and the progress of pedagogical sciences. [11]

This subject belongs to the Biology Subject that is framed within the Natural Sciences that consists of the subjects Mathematics, Chemistry, Biology and Geology. The Biology subject in turn consists of the following subjects: Biology, Ecology, Flora and Vegetation, Fauna and Microbiology. Within the biological bases, the subject Microbiology together with Ecology are essential to understand the functioning of ecosystems and the interactions between the atmospheric, 
aquatic and terrestrial environment. The microbiology subject aims to give a global vision about the microbial world and its importance within the environment. Understanding the functioning of ecosystems is impossible without knowing the impact of microbial functions on them. Knowledge of the metabolic diversity of microorganisms, the importance of microbial activities in biogeochemical cycles, the functioning of microbial communities and the interaction between microbial populations and between these and macroorganisms is essential for each and every one of the priority professional profiles grade. Knowledge of the function of microorganisms in ecosystems is essential, as is knowledge of the metabolic and physiological diversity of microorganisms. This subject will provide part of the necessary bases for the following later modules in the medical career.

The link and interaction between the affective and the cognitive can be achieved through the treatment of content. Hence, in the object under study, the microbiological content is a theoretical tool for the transmission of learning and understanding of the processes that occur at the organism level caused by biological agents that affect the correct functioning of the human being, as well as to offer Psychodidactic resources for implementation in educational practice, and develop positive attitudes aimed at social transformation. [12]

Our objective is that, after taking the course, the student has acquired a global vision about the microbial world, the impact of microorganisms in the environment and their possible use in technological processes associated with the environment. At the end of the course the student must be able to:

1. Explain the field of study of microbiology and its relationship with environmental sciences.

2. Describe the general structure of the different types of microorganisms and their diversity.

3. Manage the basic techniques of microscopy of microorganisms, stains and their applications.

4. Correctly apply the microorganism culture techniques and the different growth media: selective, differential and enrichment.

5. Explain the fundamentals of microbial genetics and the importance of the phenomena of regulation of gene expression and horizontal transfer in the evolution and metabolic diversity of microorganisms.

6. Describe the metabolic routes for obtaining energy in microorganisms and the changes they produce in the environment.

7. Explain the metabolic diversity of microorganisms and the importance of microbial activity on different ecosystems and biogeochemical cycles on a global scale.

8. List the relationships established by microbial populations within communities and the relationships they establish with higher organisms as well as apply this knowledge in the development of strategies for the microbiological control of pests and diseases. [13]

Humanity is moving towards technological development in all areas including the teaching of medicine, it is in the hands of the educator to adapt the forms of teaching to these times, maintaining motivation and instilling interest in science. [14]

The teaching of microbiology is based on both theory and practice, where the student develops conceptual, procedural and attitudinal skills. In the case of teaching and learning of this science, it is assumed that the essential thing is not to provide students with true or absolute knowledge, but to promote learning situations in which they are able to contrast and analyze various models, in addition to promoting and change certain attitudes. [15]

The subject Microbiology and Medical Parasitology, given the country's health problems, and in pandemic conditions due to the presence of COVID-19, provides us with arguments that from undergraduate are necessary to take into account and specifically in the student's preclinical cycle From the medical career, the treatment of issues related to infectious and parasitic diseases, given that they are a reason for daily consultation, and at the same time establish preventive and control measures.

\section{Conclusion}

The historical development of microbiology is linked to the need of man to know the causes of the diseases that have afflicted him over time. Thus he has elaborated mystical, miasmatic, contagionist, anti-contagionist and metaxenic conceptions to explain the natural history of all of them. But undoubtedly what gave it the greatest impetus was the invention of the microscope at the end of the 16th century, the discovery of the first microorganisms in the 17th century and the demonstration of their role in causing infectious diseases in the 19th century. The impetuous scientific-technical development achieved in this branch of medical sciences in the 20th century makes it impossible even to sketch them in their different aspects: virological, bacteriological, mycological, parasitological, immunological, biochemical, chemical, antibiotic-therapeutic and genetic, and to show the infinite field of possibilities that they offer to the future well-being of humanity, hence the importance of transmitting this knowledge to the new generations that are formed in the long journey of medicine, through the teaching-learning process.

The authors consider that the knowledge of this content is very important for doctors, medical students and other related careers.

\section{References}

[1] Núñez Jover, J. (2002). La ciencia y la tecnología como procesos sociales. Lo que la educación científica no debería olvidar. Plaza de la Revolución, Cuba: Empresa Editorial Poligráfica Félix Varela.

[2] Tian J, Sinskey AJ, Stubbe J. Kinetic studies of polyhydroxybutyrate granule formation in Wautersia eutropha H16 by transmission electron microscopy. J Bacteriol. 2005 Jun; 187 (11): 3814-24. doi: 10.1128/JB.187.11.38143824.2005. PMID: 15901706; PMCID: PMC1112049. 
[3] Scheffel A, Gruska M, Faivre D, Linaroudis A, Plitzko JM, Schüler D. An acidic protein aligns magnetosomes along a filamentous structure in magnetotactic bacteria. Nature. 2006 Mar 2; 440 (7080): 110-4. doi: 10.1038/nature04382. Epub 2005 Nov 20. Erratum in: Nature. 2006 May 11; 441 (7090): 248. PMID: 16299495 .

[4] Shih YL, Rothfield L. The bacterial cytoskeleton. Microbiol Mol Biol Rev. 2006 Sep; 70 (3): 729-54. doi: 10.1128/MMBR.00017-06. PMID: 16959967; PMCID: PMC1594594.

[5] Arango Rave Ángela. (2010). Evolución histórica de la Microbiología y el Bioanálisis en Colombia. Hechos Microbiológicos, 1 (1), 93-100. Recuperado a partir de https://revistas.udea.edu.co/index.php/hm/article/view/5228.

[6] Sosa Díaz RY, Fernández Rodríguez CJ, González Giradles R, Arana Graciaá RM. La Microbiología: historia e inserción en los planes de estudios de la Carrera de Medicina en Cuba. Rev Méd Electrón [Internet]. 2014 Ene-Feb [citado: fecha de acceso]; $36 \quad$ (1). Disponible en: http://www.revmatanzas.sld.cu/revista\%20medica/ano\%20201 4/vol1\%202014/tema12.htm.

[7] A, N. (2015). Cien años de avances en ciencias de la vida. Revista Eubacteria. $N^{\circ}$ 34. ISSN 1697-0071. 96-97. https://www.um.es/eubacteria/Microbiologia_un_siglo_de_des cubrimientos_Eubacteria34.pdf.

[8] Agenda 2030 para el desarrollo sostenible http://www.sela.org/media/2262361/agenda-2030-ylosobjetivos-de-desarrollo- sostenible.pdf (consultado agosto 2016).

[9] Guevara, R. \& Téllez, S. M. (2018). Una apuesta situada: la educación superior como objeto de investigación. Recuperado de: $\quad$ http://hdl.handle.net/20.500.12209/9422. http://repositorio.uho.edu.cu/jspui/handle/uho/4520.
[10] Etcheverry, M. G., \& Nesci, A. V. (2006). Impacto de la perspectiva histórica en la enseñanza de la Microbiología. Revista Iberoamericana De Educación, 38 (7), 1-11. https://doi.org/10.35362/rie3872611.

[11] Fernández Sacasas José Ángel. El principio rector de la Educación Médica cubana Un reconocimiento a la doctrina pedagógica planteada por el profesor Fidel Ilizástigui Dupuy. Educ Med Super [Internet]. 2013 Jun [citado 2021 Abr 30]; 27 (2): 239-248. Disponible en: http://scielo.sld.cu/scielo.php?script=sci_arttext\&pid=S086421412013000200011\&lng=es.

[12] Leyva, Y. La formación del Licenciado en Educación Biología para la transversalización del enfoque de género en el preuniversitario cubano. Tesis en opción al grado científico de Doctor en Ciencias Pedagógicas. Holguín. 2018.

[13] Madigan, M. T., Martinko, J. M., y Parker, J. Brock. Biología de los Microorganismos. 10 a edición. Prentice-Hall. Madrid, 2003.

[14] Domínguez Céspedes L, Céspedes Fonseca YM, Aguirre Ulloa Z, Maura Hernandez O, Ramírez Ramírez G. Intervención educativa sobre el Ébola para estudiantes de Medicina de. 5to año. Septiembre - noviembre 2018. CCM [Internet]. 2019 [citado 30 Abr 2021];, 23 (2):[aprox. 0 p.]. Disponible en: http://www.revcocmed.sld.cu/index.php/cocmed/article/view/ 3118.

[15] JA Aquino López. Estrategias docentes para la enseñanza de la microbiología. Tesis en opción al título académico de Máster en la enseñanza de las ciencias naturales. México. 2015. https://hdl.handle.net/20.500.12753/509. 